\title{
Differential neural responses to naturally occurring envelopes in the electrosensory system
}

\author{
Chengjie Huang $^{1 *}$, Maurice J Chacron ${ }^{1,2}$ \\ From The Twenty Third Annual Computational Neuroscience Meeting: CNS*2014 \\ Québec City, Canada. 26-31 July 2014
}

Natural sensory stimuli frequently consist of a fine structure whose amplitude (i.e. envelope) varies more slowly. Previous studies have demonstrated that envelope signals are found across sensory systems and are necessary for perception. For example, envelope signals in the auditory system carry information pertaining to the perception of pitch fluctuations in communication vocalizations [1], while envelopes in the visual system are responsible for object grouping and the perception of illusory contours $[2,3]$. However, the neural mechanisms underlying the encoding of these envelope signals are poorly understood in general. Gymnotiform wavetype weakly electric fish constitute an attractive model system for studying envelope processing in the brain because of its well-characterized anatomy and physiology [4]. These fish generate around themselves a weak quasi-sinusoidal electric field through the electric organ discharge (EOD) [5]. Recent studies have shown that the beat amplitude (i.e. the envelope) can vary in time during different behavioral contexts and display differential frequency content: while envelopes caused by movement primarily contain low $(<1 \mathrm{~Hz})$ temporal frequencies [6], those caused by social interaction instead contain higher $(>1 \mathrm{~Hz})$ temporal frequencies [7]. While it is known that electrosensory neurons can respond to envelopes [7], whether these neurons respond differentially to envelopes arising from movement and social interaction is unknown in part because their tuning to envelope frequencies has not been characterized. Here we used well established techniques [8] to record from electrosensory pyramidal neurons across different maps of the body surface within the electrosensory lateral line lobe (ELL) in response to envelope stimuli with different frequency

\footnotetext{
* Correspondence: chengjie.huang@mail.mcgill.ca

'Department of Physiology, McGill University, Montreal, Quebec H3G 1Y6, Canada

Full list of author information is available at the end of the article
}

content spanning the behaviorally relevant range (0.05$10 \mathrm{~Hz}$ ). Using standard measures of linear systems identification techniques as well as more quantitative methods of information theory, we found that pyramidal neurons in different maps displayed differential responses to envelopes arising from different behavioral contexts. Our results suggest that information about envelopes arising from different behavioral contexts begins to be segregated at the level of the ELL and provide new insights as to how these behaviorally relevant stimuli are encoded in early sensory pathways.

\section{Acknowledgements}

This work was funded by CIHR and FQRNT.

\section{Authors' details}

${ }^{1}$ Department of Physiology, McGill University, Montreal, Quebec H3G 1Y6, Canada. ${ }^{2}$ Department of Physics, McGill University, Montreal, Quebec H3G 1Y6, Canada.

Published: 21 July 2014

\section{References}

1. Burns EM, Viemeister NF: Played-again SAM: Further observations on the pitch of amplitude-modulated noise. Journal of Acoustical Society of America 1981, 70:1655-1660.

2. Shapley R: Visual cortex: pushing the envelope. Nature neuroscience 1998, 1(2):95-96.

3. Grosof DH, Shapley RM, Hawken MJ: Macaque V1 neurons can signal 'illusory' contours. Nature 1993, 365(6446):550-552.

4. Maler L: Receptive field organization across multiple electrosensory maps. I. Columnar organization and estimation of receptive field size. The Journal of comparative neurology 2009, 516(5):376-393.

5. Bennett MV: Electrolocation in fish. Annals of the New York Academy of Sciences 1971, 188:242-269.

6. Fotowat $\mathrm{H}$, Harrison RR, Krahe R: Statistics of the electrosensory input in the freely swimming weakly electric fish Apteronotus leptorhynchus. The Journal of neuroscience: the official journal of the Society for Neuroscience 2013, 33(34):13758-13772.

7. Stamper SA, Fortune ES, Chacron MJ: Perception and coding of envelopes in weakly electric fishes. The Journal of experimental biology 2013, 216(Pt 13):2393-2402.

8. Deemyad T, Metzen MG, Pan Y, Chacron MJ: Serotonin selectively enhances perception and sensory neural responses to stimuli generated
() Biomed Central

(C) 2014 Huang and Chacron; licensee BioMed Central Ltd. This is an Open Access article distributed under the terms of the Creative Commons Attribution License (http://creativecommons.org/licenses/by/4.0), which permits unrestricted use, distribution, and reproduction in any medium, provided the original work is properly cited. The Creative Commons Public Domain Dedication waiver (http://creativecommons.org/publicdomain/zero/1.0/) applies to the data made available in this article, unless otherwise stated. 
by same-sex conspecifics. Proceedings of the National Academy of Sciences of the United States of America 2013, 110(48):19609-19614.

doi:10.1186/1471-2202-15-S1-P192

Cite this article as: Huang and Chacron: Differential neural responses to

naturally occurring envelopes in the electrosensory system. $B M C$

Neuroscience 2014 15(Suppl 1):P192.

Submit your next manuscript to BioMed Central and take full advantage of:

- Convenient online submission

- Thorough peer review

- No space constraints or color figure charges

- Immediate publication on acceptance

- Inclusion in PubMed, CAS, Scopus and Google Scholar

- Research which is freely available for redistribution

Submit your manuscript at 